http://dx.doi.org/10.4314/gjl.v7i2.6

\title{
"PADDLING A CANOE AND PREPARING RICE BALLS": THE SEMANTICS OF TAFI CUISINE
}

\author{
Mercy Bobuafor
}

\begin{abstract}
The culinary field is where three of the well-authenticated examples of human universals; tool making, use of fire and cooking of food, come together. Yet in this field, cultures differ in their conceptualisation and linguistic representation of food preparation. In this study, I discuss the language of cooking in Tafi, a Ghana-Togo Mountain Language, focusing on five verbs: tó "cook, boil"; púi "bake, roast", gba "fry, roast; sweep"; ge "cook (e.g. dumpling); drive (e.g. a car)" and tú "pound". I investigate the semantic relations among them and explore the cultural logic that unites the interpretations suggested by their translation equivalents. Thus, I show that the contextual interpretation of to depends on the classes of nouns it collocates with: With kíd̄ "thing" it signals "prepare a meal". Where its complement is a specific product, the interpretation is "to make something" e.g., tó bésh(e)okõ $\tilde{\varepsilon}$ "prepare local soap". But if the complement names a food then it means "prepare that particular food" e.g. tó (elí) oni "prepare (oil-palm) soup". If the complement is a (raw) foodstuff, it is interpreted as "boil in water to", e.g. tó kídze "egg" is interpreted as "cook egg" or "boil egg in water". Furthermore, I argue that the use of the activity verbs gba "sweep", ge "drive, paddle" (cf. Akan ka) and tú "pound" in the culinary field is based on the manner of food preparation. The Tafi conceptualisations and lexicalisation patterns will be compared to the vocabulary in Ewe and Akan to discover the similarities and differences.
\end{abstract}

Keywords: Food preparation, lexicalisation pattern, polysemy, Tafi and verb semantics 


\section{Introduction}

A categorial opposition between the raw and the cooked is a universal experience. Universally also the mediums through which food is cooked tend to be similar: fire, water, fat (or oil) etc. What is striking is that different cultures have different ways of preparing and cooking food. They also construe and interpret the processes differently. For instance, the cooking of banku-like ${ }^{1}$ foods is described differently in different Ghanaian languages, as we shall see below. The Ewe use the verb "cook" for that and do not pay attention to the manner of cooking. The Tafi and the Akan describe it in terms of the activity and manner of movement of, and the turning of the ladle. Thus, they use the verb that also means to drive a car (or perhaps more accurately to steer) or to paddle or row to talk about it. The goal of this paper is to explore the ways in which the Tafi people of south-eastern Ghana talk about the different modes of preparing the food that they eat. This will be done through an examination of the grammar and especially the semantics of five verbs that can be said to belong to the culinary field in the language (see Lehrer 1974 for English cooking verbs). The verbs involved can be divided into two groups: the verbs in the first group focus on preparing food through a medium: tó "cook, boil"; pứ "bake, roast"; gba "fry, roast; sweep" and those in the second group focus on the vigorous physical activity that the cook performs: ge "drive, paddle" and tú "pound". The various translation equivalents of the verbs provide some clues to the significance of the verbs.

In the exploration of the syntax and semantics of lexical units in the lexical field of cooking and cuisine in Tafi, the field semantics and frame semantics perspectives will be adopted. A semantic field or lexical field is a group of words or lexical units that share a semantic feature. They also have paradigmatic relations with each other. A lexical field approach to semantics was introduced by Trier (1931) (see Lyons 1977), and Lehrer (1974) applied this approach to the analysis of cooking terms in English and other European languages. As Lehrer and Kittay (1992:4) note later, the advantage of lexical field analysis is that the meaning of a word is understood in relation to other words in the same domain. These relations could be in terms of synonymy, antonymy, hyponymy or incompatibility. From this point of view, relations are part of the meaning of the word. In Table 1, the relations holding between the cooking verbs in Tafi, hyponymy and incompatibility can be inferred from the representation. As Lehrer and Kittay (1992:4) illustrate, "to understand

$1 \quad B a n k u$ is the Ga name for a starchy component of a meal prepared with corn dough. People also add cassava dough to the corn dough. The term has been borrowed into other Ghanaian languages including Ghanaian English. 
the meaning of the verb to sauté requires that we understand its contrastive relation to deep fry, broil, boil, and also the affinitive terms like cook and the syntagmatic relations to pan, pot, and the many food items one might saute'". In the discussion of the meanings of the cooking terms, their relations to say the food items that are prepared that way will be considered.

Apart from knowing how the terms in the field are related and their contribution to the meaning, we can also understand a term in terms of the semantic frame to which it belongs. A semantic frame is a domain of experience including cultural experience that a lexical item evokes. It is assumed that there is a knowledge structure associated with each linguistic sign (encyclopaedic knowledge), parts of which are evoked in particular contexts (Fillmore 2006[1982], Atkins and Fillmore 1992, Petruck 1996). For instance, I will show below that one of the verbs that belongs to the lexical field of cooking ge "paddle, row, drive" evokes in particular usages knowledge structures and elements associated with food preparation/cooking (e.g. preparing rice balls ${ }^{2}$, banku, as well as ladle, heat source, an effector etc.), vehicular transport frame (e.g. car, steering wheel, a driver), water transport frame (e.g. canoe, boat, paddle, an effector, water bodies etc.).

The frames evoked and the frame elements are critical for the realisation of the event. An aspect of frame semantics is the PARTICIPANTS. For this verb ge, as indicated by the frames above, there must be the following Participant roles even if they are not realised in particular usages: an AGENT or Effector of the action (i.e. the one who is preparing the rice balls, for example); an INSTRUMENT that the AGENT handles to bring about a change of state or to produce something (i.e. the wooden ladle manipulated to create the paste); a THEME, i.e. the entity whose movement or state is at stake; and MANNER the way in which the AGENT carries out the action to produce an effect, or a change.

While for each of the sub frames evoked, the participants are different entities, it seems that the MANNER in which the agent handles the INSTRUMENT to produce an effect in the THEME (causing it to move in a particular direction [TRANSPORT] or to become something else [FOOD PREPARATION] is similar. It appears that this is the logic that unites these seemingly disparate frames. Before turning to the discussion of the verbs, I first provide the typological features of Tafi, relevant for interpreting the examples. The rest of the article is structured as follows: the general verb of cooking to "cook" is discussed in section 2. The third section is devoted to the discussion of the verb gba "fry, roast" while the fourth section deals with the verb pưi "bake, roast". Specific activity verbs of food

2 Rice balls is a dish prepared by mashing boiled rice and moulding it into balls. This dish is usually eaten with soup, e.g., groundnut or palm nut soup. 
preparation - ge "cook (dumpling); drive (e.g. a car); paddle/row (a canoe)" and tú "pound" are examined in the fifth section and the final section is the conclusion.

\subsection{Some typological features of Tafi}

The Tafi language is spoken in the south-eastern part of Ghana by about 4,400 people (2003 figures). The Tafi people refer to their language as Tigbo and to themselves as Bagbo (Simons et al. 2018). Tafi belongs to the KA subgroup of the Ghana-Togo-Mountain (GTM) languages which belong to the Kwa family of the Niger-Congo phylum. Tafi and its neighbour Nyagbo (Tutrugbu) are highly mutually intelligible and it is also closely related to Avatime (Siya) (see e.g. Bobuafor 2013, Defina 2016, Essegbey 2010, van Putten 2014).

Tafi has nine vowels which participate in a root-controlled ATR harmony system. It is a tone language with three level tonemes: High (marked with an acute accent), Mid (marked with a macron) and Low (left unmarked or with a grave accent on syllabic nasals) plus Rising $(\mathrm{R})$ and Falling $(\mathrm{F})$ tones.

Like most of the other GTM languages, Tafi has an active system of noun classes identified by prefixes and a system of agreement markers. At the clause level, the subject is cross-referenced on the verb. The basic constituent orders of Tafi are SV/AVO and AVDO. The possessor precedes the possessed. Pragmatically salient constituents with topic and focus functions occur in the left-periphery of the clause (see Bobuafor 2013).

Tafi is a verb serialising language like most Kwa languages where the subject is expressed only once and the verbs share the same tense and mood but can be independently marked for compatible aspect values (see Bobuafor 2009, 2013).

Tafi has only three underived simple adjectives. Ideophones and derived adjectivals are used as qualifiers in NPs. Property verbs can be reduplicated and used to predicate qualities of subject NPs in clauses.

\section{The verb tó}

The verb tó is a bivalent verb that entails two participants, an Actor and an Undergoer. It cannot occur in a one-place (intransitive) construction. It typically occurs in a two-place (transitive) construction. When it occurs in a two-place construction, it can be extended 
with a dative (1) or locative participant (2) as illustrated in the elicited sentences in (1) and $(2) .^{3}$

1. Ésí átó 'ćdō kó 'ál'.

$\begin{array}{lllll}\text { Ésí } & \text { á-tó } & \text { kí-d̄̄ } & \text { kó } & \text { balí } \\ \text { Ésí } & \text { SM-cook } & \text { CM-thing } & \text { DAT } & 3 P L\end{array}$

'Esi cooked for them.'

\section{2. Ésí átó 'ćd̄̄ ní osubhanıabhā.}

$\begin{array}{lllllll}\text { Ésí } & \text { á-to } & \text { kí-d̄̄ } & \text { ní } & \text { o-subha } & \text { ní } & \text { kábhā } \\ \text { Esi } & \text { SM-cook } & \text { CM-thing } & \text { LOC } & \text { CM-hearth } & \text { DEF } & \text { top }\end{array}$

'Esi cooked on the hearth.'

The verb has three readings depending in part on the semantics of the complement it takes. Its general sense is to make or prepare something such as soap (3) or palm oil (4). ${ }^{4}$

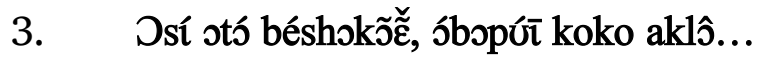 \\ o-sí o-tó bé-she.okõ $\tilde{\varepsilon}$ o-bo-pữ koko a-klô \\ 2SG-say SM-cook CM-local.soap 2SG-FUT-roast cocoa CM.PL-pod \\ 'If you want to prepare local soap, you will burn cocoa pods...' (Local soap)}

\section{Kánā gı lát̄̄ 'udzo ní Baagbo.}

$\begin{array}{llllll}\text { ká-nā } & \text { gi } & \text { lá-t̄̄ } & \text { bu-dzo } & \text { ní } & \text { Baagbo } \\ \text { CM-manner } & \text { REL } & \text { 3PL.DEP-cook } & \text { CM-palm.oil } & \text { LOC } & \text { Tafi } \\ \text { 'This is how palm oil is prepared in Tafi.' (Palm oil) } & & \end{array}$

When the complement of the verb is the generic nominal kíd̄̄ 'thing' the general reading is to prepare a meal, to cook. In the sentence in (5), it is clear that the rooster was killed and a meal was prepared with it. The verb here refers to the whole event.

3 In this paper, the examples are presented in four (4) lines. The first line represents the spoken form and shows word divisions. In the second line, the data is presented in bold with hyphens (-) symbolising morpheme breaks. The morphs in the first line are fully spelt out as morphemes in the second line thus initial consonants andsyllables deleted are presented in their recoverable forms. The interlinear gloss and a free English translation provided in single quotes are given in the third and fourth lines respectively.

$4 \quad$ Where the example is taken from a text example, the name of the text is indicated and these can be found in Chapter 13 of Bobuafor (2013). 
5. Évu y’ókưkóny'oní, eyí, átó 'éd̄o.

\begin{tabular}{|c|c|c|c|c|}
\hline é-vu & yí & o-kúkónye & o-ní & e-yí \\
\hline 3SG-catch & 3SG.IND & CM-rooster & AM-PROX & SM-kill \\
\hline a-tó & kí-d̄̄ & & & \\
\hline SM-cook & CM-thing & & & \\
\hline
\end{tabular}

Similarly, in (6) there is disapproval being expressed concerning the quantity of oil that was used in preparing a meal.

6. Átó ' '

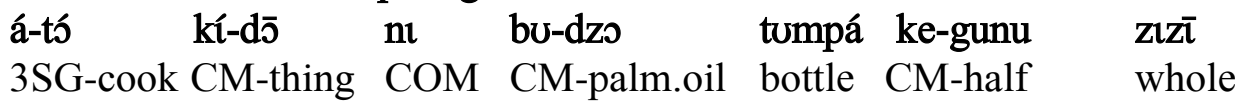

'She used half bottle of oil to cook.' (lit. 'she cooked with a whole half bottle of oil.')

7. Śboto 'edōń lóó óbovı ti shui 'uní?

$\begin{array}{llllll}\text { ó-bo-tó } & \text { kí-d̄̄ } & \text { ní lóó } & \text { ó-bo-vı } & \text { tı } \\ \text { 2SG-FUT-cook } & \text { CM-thing } & \text { DEF } & \text { DISJ } & \text { 2SG-FUT-go PURP } \\ \text { shui bu-ní } & & & & \\ \text { fetch CM-water } \\ \text { 'Will you cook the food or you will go to fetch water (from the riverside)?' }\end{array}$

When the complement is specific and refers to food such as soup or rice dumpling, the interpretation is to prepare or cook that particular dish. Consider examples (8) - (10).

8. Plơnō ní óbośk̄̄ akpã̃ óbośk' ot'óní nō.

\begin{tabular}{|c|c|c|c|c|}
\hline plứn̄ ní & 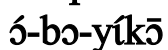 & & a-kpã̃ & う-bo-yúk̄̄ \\
\hline TOP & 2SG-FUT & & CM.PL-fish & SM-FUT-take \\
\hline ó-tó & o-ní & $\mathrm{n} \overline{\mathrm{D}}$ & & \\
\hline SM-cook & CM-soup & $\mathrm{COM}$ & & \\
\hline
\end{tabular}

'In addition, you will use fish in preparing soup.' (Kımukó, line 04)

9. Bưtó ádoy' óni pétéé n'elí lo.

$\begin{array}{lllll}\text { bú-tó } & \text { á-doyí } & \text { o-ní } & \text { pétéé } & \mathbf{n} \mathbf{} \\ \text { 1PL-cook } & \text { CM.PL-bean } & \text { CM-soup } & \text { all } & \text { COM }\end{array}$




\section{e-lí lo \\ CM.PL-palm.nut ADD \\ 'We prepare peas soup using palm nuts.' (Kımukó, line 09)}

10. Báátó 'emukś ní Baagbo.

$\begin{array}{lll}\text { bá-á-tó } \quad \text { kt-mukś } & \text { [ní } & \text { Baagbo }] \\ \text { 3PL-PRSPROG-cook CM-red.rice.dumpling } & \text { LOC } & \text { Baagbo } \\ \text { 'They are cooking red rice dumpling in Tafi. }{ }^{5} & & \end{array}$

When the complement of the verb refers to an ingredient such as yam (11), palm-nut (12) or rice (13) rather than a dish as in (8) - (10) above, the interpretation can be rendered as 'boil in water to cook'.

11. Adzīin ábato ekūń alóó ábad'alí?

$\begin{array}{llllll}\text { a-dzı } & \text { ní } & \text { á-ba-tó } & \text { é-kū } & \text { ní } & \text { alóó } \\ \text { CM-woman } & \text { DEF } & \text { SM-FUT-cook } & \text { CM.PL-yam } & \text { DEF } & \text { DISJ } \\ \text { á-ba-dı } & \text { alí } & & & & \end{array}$

SM-FUT-sell 3PL

'Will the woman cook the yams or she will sell them?'

12. Ábató élín owūlago.

á-ba-tó

e-lí

ní

0-wūlago

3SG-FUT-cook

CM.PL-palm.nut DEF

CM-evening

'S/he will boil the palm nuts in the evening.'

13. Át'ôn'ôní kulí y’átó ás’âní kulí ááko 'elí pétéé áákś abal'akpt ketsukpú gbugblă gbugblă gbugblă gbugblă gbugblă tielím̄̄ kilí áák̄̄ édōn áda.

\begin{tabular}{lllllll} 
á-tó & o-ní & o-ní & \multicolumn{1}{c}{ kllí } & yí & \multicolumn{2}{c}{ a-tó } \\
3SG-cook & CM-soup & AM-PROX & CONJ & 3SG.IND & SM-cook \\
á-sí & a-ní & kvlí & á-yíko & klí & pétéé & á-yíkś \\
CM-rice & AM-PROX & CONJ SM-take & 3SG & all & SM-take \\
a-balı & a-kpí & ke-tsukpú & gbugblă & gbugblă \\
SM-pour & SM-put.in & CM-pot & big & big & \\
gbugblă & gbugblă & gbugblă & tie-lí & kımı
\end{tabular}

$5 \quad$ Kımoḱ 'red rice dumpling' is a dish prepared with flour prepared from roasted red rice. 


\begin{tabular}{llllll} 
big & \multicolumn{1}{r}{ big } & & big & & AM-INDEF in \\
kılí & á-yíks & kí-d̄̄ & ní & á-da & \\
CONJ & SM-take & CM-thing & DEF & SM-cover
\end{tabular}

'She prepared this soup and cooked this rice and she put it all into a very

big pot and covered it.' (Kasalã, line 243)

In the first line in (13), two readings of the verb are juxtaposed. It is the second use of the verb with its complement as rice that we are interested in here. It just involves putting the ingredient rice on fire, adding water and letting it boil to cook. This is unlike the first use which entails a few more actions like the addition of other ingredients such as fish and vegetables in order to prepare soup.

A piece of evidence that the reading of 'boil in water to cook' of the verb tó entails both phases, namely 'boiling in water' and 'become.cooked', is that there is another verb which translates as 'boil' but which focuses on the vigorous activity of boiling and does not entail 'being cooked'. As the fragment in (14) shows the 'be cooked' verb bí will be needed to express the result of the boiling denoted by the verb yabá 'become hot to boiling point'.

14. ... gi bubaziyabá g'lǔ babí.

gl bu-ba-zl-yabá gi lǔ-ba-bí

REL 3SG-FUT-REP-boil REL 3SG.DEP-FUT-be.cooked

'...while it continues boiling until it is done (cooked).' (Palm oil, line 35)

The verb tó can be nominalised through noun class prefixation. Thus, in the proverb in (15), kı-tó 'cooking' is a nominalised form of the verb.

15. Ań̛vō ní gi ákányó edí ní y’ádo así y’eni y’ényí 'ító dí.

$\begin{array}{lllllll}\text { a-nớvō } & \text { ní } & \text { gi } & \text { á-ká-nyó } & \text { e-dí } & \text { ní } \\ \text { CM-child } & \text { DEF } & \text { REL } & \text { 3SG.DEP-NEG.PERF-roam } & \text { SM-look } & \text { TOP } \\ \text { yí } & \text { á-do } & \text { a-sí } & \text { yí } & \text { é-nī } & \\ \text { 3SG.IND } & \text { SM-say } & \text { SM-COMP } & \text { 3SG.IND } & \text { CM-mother } & \\ \text { yí } & \text { é-nyí } & \text { kı-tó } & \text { dí } & & \\ \text { 3SG.IND } & \text { SM-know } & \text { CM-cook } & \text { surpass } & & \end{array}$

'The child who has never travelled says that his mother is the best cook.' (lit. 'the child who has never travelled says his mother's cooking surpasses all.')

(Proverbs \#49) 
In sum, the verb tó has three readings generated in composition with the semantics of the complement it takes: a general meaning of make or prepare something or make something such as soap, palm oil or prepare a meal; and specific readings of cook a dish, e.g., rice dumpling; palm nut soup, and boil to cook e.g. rice, yam etc. The question is whether each of these readings is a distinct sense or not. In Table 1, I show the hierarchical relation between the senses and in Table 2, I compare some collocational patterns involving the verb and its counterparts in Ewe, Akan and Ga. Table 2 shows that while the cook verb is used in Tafi to talk about preparing and cooking soups, Ewe uses a 'hit' verb to express that idea. Table 2 also shows that while Ewe uses the general 'cook, prepare a meal' verb to talk about the preparation of banku or akple or dumpling, Tafi uses an activity verb of manner ge 'drive, paddle' for that event, similar to Akan.

Table 1: Tafi cooking verbs

\begin{tabular}{|c|c|c|c|c|}
\hline \multicolumn{5}{|c|}{ tó 'prepare something or meal' } \\
\hline \multicolumn{4}{|c|}{ tó 'cook a specific dish' } & \multirow[b]{2}{*}{ tú 'pound } \\
\hline tó 'boil to cook' & $\begin{array}{l}\text { púī 'bake, roast, } \\
\text { char grill' }\end{array}$ & $\begin{array}{l}\text { gba 'fry, roast; } \\
\text { sweep' }\end{array}$ & $\begin{array}{l}\text { ge 'drive, steer, } \\
\text { paddle, row' }\end{array}$ & \\
\hline+ water & $\begin{array}{l}\text { Open or enclosed } \\
\text { dry heat; direct } \\
\text { contact with fire } \\
\text { coals }\end{array}$ & $\begin{array}{l}\text { Cook in fat, or } \\
\text { fine powder as } \\
\text { heat conduit, } \\
\text { over high heat }\end{array}$ & $\begin{array}{l}\text { Mix flour or } \\
\text { dough with } \\
\text { water and cook } \\
\text { on fire by } \\
\text { stirring using a } \\
\text { wooden stick till } \\
\text { it forms a thick } \\
\text { paste }\end{array}$ & \\
\hline
\end{tabular}


Table 2: Collocational patterns of cooking verbs in Tafi, Ewe, Akan and Ga

\begin{tabular}{|c|c|c|c|c|}
\hline & Tafi & Ewe & Akan & $\mathrm{Ga}$ \\
\hline $\begin{array}{l}\text { Cook, prepare a } \\
\text { meal }\end{array}$ & $\begin{array}{l}\text { tó kí-d̄̄ cook } \\
\text { thing' }\end{array}$ & $\begin{array}{l}\text { da nu 'cook } \\
\text { thing' }\end{array}$ & $\begin{array}{l}\text { noa aduane } \\
\text { 'cook food' }\end{array}$ & $\begin{array}{l}\text { hoo niyenii } \\
\text { 'cook food' }\end{array}$ \\
\hline $\begin{array}{l}\text { Make, prepare } \\
\text { soap }\end{array}$ & 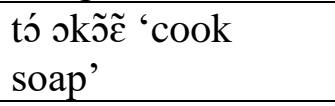 & da adzalẽ/kəe & $\begin{array}{l}\text { ye samina } \\
\text { 'make soap' }\end{array}$ & $\begin{array}{l}\text { fee samla } \\
\text { 'make soap' }\end{array}$ \\
\hline $\begin{array}{l}\text { Boil cook egg, } \\
\text { yam, rice }\end{array}$ & tó 'cook' & da 'cook' & noa 'cook' & hoo 'cook' \\
\hline $\begin{array}{l}\text { Make, prepare } \\
\text { soup }\end{array}$ & tó oni' 'cook soup' & $\begin{array}{l}\text { fo detsi 'hit } \\
\text { soup' }\end{array}$ & $\begin{array}{l}\text { bo/ye nkwan } \\
\text { 'hit/make } \\
\text { soup' }\end{array}$ & $\begin{array}{l}\text { hoo wonu } \\
\text { 'cook soup' }\end{array}$ \\
\hline Distil alcohol & $\begin{array}{l}\text { tó bulu/ akpeteshi } \\
\text { 'cook } \\
\text { drink/akpeteshie' }\end{array}$ & $\begin{array}{l}\text { da aha/ } \\
\text { akpeteshi 'cook } \\
\text { drink/ } \\
\text { akpeteshie }\end{array}$ & $\begin{array}{l}\text { noa nsa/ } \\
\text { apetehyi } \\
\text { ‘cook } \\
\text { drink/ } \\
\text { akpeteshie }\end{array}$ & $\begin{array}{l}\text { hoo } \\
\text { akpeteshi } \\
\text { 'cook } \\
\text { akpeteshie' }\end{array}$ \\
\hline Boil water & $\begin{array}{l}\text { tó buní 'cook } \\
\text { water' }\end{array}$ & & $\begin{array}{l}\text { noa nsu } \\
\text { 'cook water' }\end{array}$ & $\begin{array}{l}\text { too nula } \\
\text { 'heat hot } \\
\text { water }\end{array}$ \\
\hline $\begin{array}{l}\text { Boil leaves for } \\
\text { medicine }\end{array}$ & $\begin{array}{l}\text { tó bowá 'cook } \\
\text { medicine' }\end{array}$ & $\begin{array}{l}\text { da amatsi 'cook } \\
\text { medicine' }\end{array}$ & $\begin{array}{l}\text { noa } \\
\text { nhahamma } \\
\text { 'cook leaves' }\end{array}$ & $\begin{array}{l}\text { hoo tsofa } \\
\text { 'cook } \\
\text { medicine' }\end{array}$ \\
\hline Sterilise & $\begin{array}{l}\text { tó /kahukpó/ } \\
\text { katsrokpó/ kíp̄̄ } \\
\text { 'cook hand/ foot/ } \\
\text { wound/ sore' }\end{array}$ & $\begin{array}{l}\text { da asi/ afo } \\
\text { 'cook hand/ } \\
\text { foot' }\end{array}$ & & $\begin{array}{l}\text { hoo nane } \\
\text { 'cook foot' }\end{array}$ \\
\hline Cook dumpling & $\begin{array}{l}\text { ge kıkó } \\
\text { 'drive/paddle } \\
\text { dumpling' }\end{array}$ & $\begin{array}{l}\text { da akple 'cook } \\
\text { dumpling' }\end{array}$ & $\begin{array}{l}\text { ka abetee } \\
\text { 'drive } \\
\text { dumpling' }\end{array}$ & $\begin{array}{l}\text { tsí bayku } \\
\text { 'cook } \\
\text { dumpling' }\end{array}$ \\
\hline $\begin{array}{l}\text { Cook porridge, } \\
\text { rice water }\end{array}$ & $\begin{array}{l}\text { hu kókó 'hit } \\
\text { porridge' }\end{array}$ & $\begin{array}{l}\text { fo kókó 'hit } \\
\text { porridge' }\end{array}$ & $\begin{array}{l}\text { ka mpampa, } \\
\varepsilon \text { mo nsuo } \\
\text { 'drive } \\
\text { porridge' }\end{array}$ & $\begin{array}{l}\text { hoo kókó, } \\
\text { raiswota } \\
\text { 'cook rice } \\
\text { water' }\end{array}$ \\
\hline
\end{tabular}




\section{The verb gba}

The verb gba is also a bivalent verb which occurs in two-place (transitive) constructions. As shown in Table 1, the verb has three readings. Two of the readings relate to food preparation. One of the readings is that of cooking something in hot oil or fat; that is, fry as in (16).

16. Hm! adzīn ágbe edútsū uní.

hm a-dzı $\quad$ ní á-gba $\quad$ i-dútsū l-ní

INTJ CM-woman DEF SM-fry CM.PL-stew AM-PROX

'Um, the woman made these stews.' (Kasalã, line 242)

In this example, stews have been cooked and the use of the verb gba signals that the cooking was done in heated oil.

A second reading related to cooking is that of cooking something in dry heat over high fire in an open container. The result is something that is cooked and dry. This applies especially to grains, nuts and flour. In this reading, the verb is translated as 'roast'. Consider the examples in (17) and (18) describing how red-rice is treated before being cooked into dumpling.

17. Blǒ ní, bútú ká logba é.

$\begin{array}{llllll}\text { blš } & \text { ní } & \text { bú-tú } & \text { ká } & \text { lo-gba } & \text { é } \\ \text { 1PL.IND } & \text { TOP } & \text { 1PL-pound } & \text { then } & \text { 1PL.DEP-roast } & \text { CFM }\end{array}$

'As for us, we pound (the rice) and then roast it.' (Kımukó, line 05)

18. Búagbá n’ogbadzéćm ká lodoho é.

\begin{tabular}{|c|c|c|}
\hline j-ba-gbá & & o-gbadzá \\
\hline PL-FUT-roast & LOC & CM-roasting.pan \\
\hline lo-do-ho & & é \\
\hline
\end{tabular}

'We will roast (it) in a roasting pan then we go and grind (it).' (Kımukó, line 06)

The difference in the medium of cooking between the two readings supports a polysemic account. There is a further reading of the verb gba 'sweep' outside the cooking domain. Examples 19-21 illustrate the 'sweep' sense of the verb. 
19. Kíwinyééwī adzīn agbe 'edō.

$\begin{array}{lllll}\text { kí-wī-nyáá-kí-wī } & \text { a-dzı } & \text { ní } & \text { á-gba } & \text { kí-d̄̄ } \\ \text { CM-day-DISTR-CM-day } & \text { CM-woman } & \text { DEF } & \text { SM-sweep } & \text { CM-thing }\end{array}$

'Everyday, the woman sweeps.' (Bobuafor 2013: 228 ex. 172)

20. Ónúgi áányā kóráá tsyí ábagba 'uvuním.

$\begin{array}{ll}\text { ónú.gı á-á-nyā kóráá tsyí á-ba-gba } \\ \text { COND } & \text { 3SG.DEP-PRSPROG-be.sick even too 3SG-FUT-sweep } \\ \text { bú-vū } & \text { ní kimı } \\ \text { CM-house } & \text { DEF inside } \\ \text { 'Even if s/he is sick s/he will sweep the room.' (Bobuafor 2013: 298, ex. 113) }\end{array}$

21. Imosa tutá tlí láayíko agbá kikpekpením flôgo pr abaho asrá vuvo akpí.

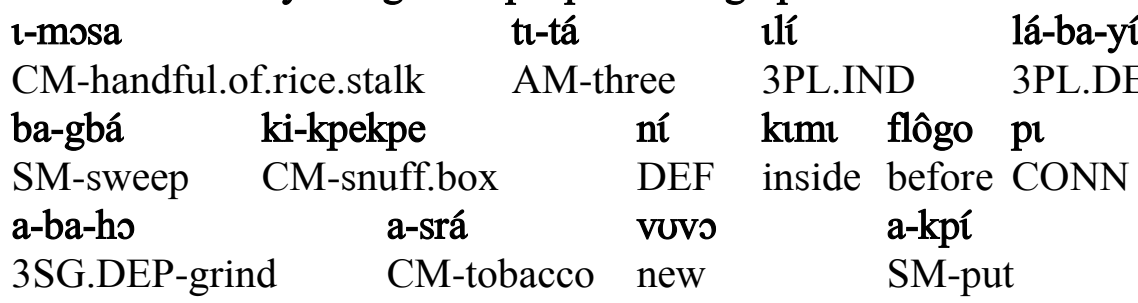

'It is three handfuls of rice stalks that will be used to clean the inside of the snuff-box before she will grind new tobacco to put into it.' (Sã́hwĩ ) (Bobuafor 2013: 292-3)

The question has to be asked whether the sweep interpretation is a related sense or we would have to consider the verb with that reading, a different lexical item in homonymous relation to the cooking verb. I submit that the sweep sense is related to and linked to the cooking verb hence one polysemous verb. The common denominator of the actions associated with the three readings is the movement an agent makes in bringing about the realisation of the event involved. Think about the sweeping movements and the movements of turning things being fried and especially entities such as flour and grains being roasted. Table 3 summarises various collocational patterns of the cooking senses of the verb and the equivalents in related languages. 
Table 3: Collocational patterns of gba compared

\begin{tabular}{|l|l|l|l|l|}
\hline & Tafi & Ewe & Akan & Ga \\
\hline Fry plantain, yam & gba & to & kyé & shĩ \\
\hline $\begin{array}{l}\text { Heat to boil of oil, } \\
\text { make stew }\end{array}$ & gba & $\begin{array}{l}\text { to / wo atadi } \\
\text { 'make stew' }\end{array}$ & yé 'make' & fee 'make' \\
\hline $\begin{array}{l}\text { Roast grain (e.g.) } \\
\text { rice, maize, } \\
\text { peanuts, nuts }\end{array}$ & gba & to & kyé & shĩ \\
\hline Roast gari & gba & to & kyé & shĩ \\
\hline
\end{tabular}

From the table, it is apparent that there is a logic that unites what in English is expressed as 'fry' and 'roast' which is shared by the linguacultures in southern Ghana and in fact beyond. The analysis presented here shows that we need to go beyond translation equivalents to understand the cultural logics of verbs.

\section{The verb pói}

The verb pói is translated in context into English as 'bake', 'roast', 'grill' or 'char-grill' depending on the nature of the heat and whether there is contact with live charcoal as source of heating for the cooking. Thus, if the cooking is done in an enclosed dry heat environment where the ingredient is not in direct contact with the heat generating entity, e.g. in an oven, then the verb is translated as bake or roast. The ingredient could also be cooked on a frame where it is not in direct contact with the heat generating entity. This is also translated as roast (see image below of roasted plantain in Fig 1). The ingredient can also come in direct contact with the heat generating entity such as the charcoal as is the case of the maize in Fig 2.

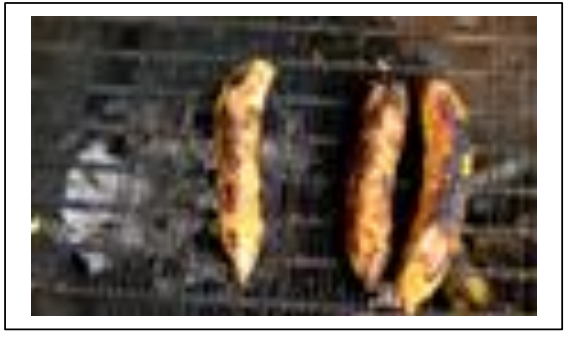

Fig 1: roasted plantain

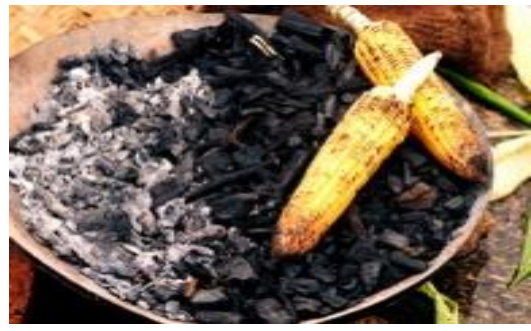

Fig 2: roasted maize 
Thus, the roasting talked about in example 22 can be done either with direct heat or without as in the figures. Example 23 shows that the ingredient cooked in this way can be meat also.

22. Adzın eéw̃úsē bladzyó tı apứi.

a-dzı ní e-é-w̃úsé

CM-woman DEF SM-PRSPROG-peel plantain PURP

a-púi

3SG.DEP-roast

'The woman is peeling plantains to roast.'

\section{3. Ákó lapơi kıdzyań.}

$\begin{array}{llll}\text { á-ḱ́ } & \text { la-púi } & \text { kı-dzya } & \text { ní } \\ \text { 3SG-cause } & \text { 3PL.DEP-roast } & \text { CM-meat } & \text { DEF }\end{array}$

' $\mathrm{S} /$ he made them roast the meat.' = char grill

Food preparation that is done in an enclosed heated environment, i.e. oven, is also described with this verb. Thus, the baking of bread is described with the same verb. Equivalents of this verb with a similar range of uses are found in the neighbouring languages as well, as demonstrated in Table 4.

Table 4. Collocations of póĩ compared

\begin{tabular}{|l|l|l|l|l|}
\hline & Tafi & Ewe & Akan & Ga \\
\hline $\begin{array}{l}\text { Roast/char grill, } \\
\text { plantain, yam } \\
\text { fish, meat } \\
\text { (direct/open dry } \\
\text { heat) }\end{array}$ & púi & me & toto & shã \\
\hline $\begin{array}{l}\text { Bake bread, etc } \\
\text { (enclosed dry } \\
\text { heat) }\end{array}$ & pới & me & to & shã \\
\hline $\begin{array}{l}\text { Burn (in } \\
\text { enclosure) e.g. } \\
\text { charcoal }\end{array}$ & púĩ & me & hye & shã \\
\hline
\end{tabular}


Bobuafor: "Paddling A Canoe and Preparing Rice Balls": The Semantics of Tafi Cuisine

\begin{tabular}{|l|l|l|l|l|}
\hline $\begin{array}{l}\text { Burn (as in cause } \\
\text { pain e.g. from a } \\
\text { hot entity e.g. } \\
\text { iron) }\end{array}$ & me & hye & shã \\
\hline Burn paper & póì & tó dzo 'set fire' & hye & shã \\
\hline
\end{tabular}

\section{Specific activity verbs of food preparation}

The verbs discussed so far describe general food preparation. We now turn to specific verbs for talking about particular activities carried out in the preparation of some aspect of the meals. We focus on two verbs that describe activities associated with two salient foods of the Tafi - kık' 'dumpling' and fufuó 'fufu' ${ }^{6}$

\subsection{The verb ge}

The verb ge is a general verb that is glossed as 'drive, steer' something. In the culinary domain, it is specialised for describing the movements a cook makes while preparing a dumpling-like food. Example (24) taken from a procedural text describing how a local ritual and ceremonial food kımukó 'red.rice dumpling' is made in Tafi. The particular example talks about the things that happen before one begins to 'drive' the flour in the water to make the dumpling.

\section{Okónín buttibatsı kpí ko gi lóoge?.}

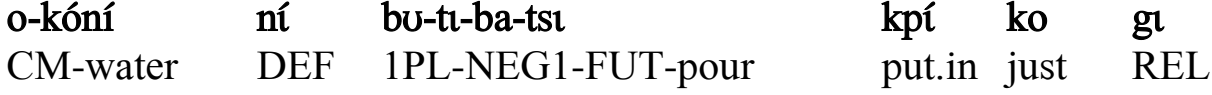

ló-bo-ge

1PL.DEP-FUT-drive

'We don't just add the flour to the water and start stirring (it).'

$6 \quad$ A reviewer wonders how this distinction between general food preparation verbs and specific verbs is motivated. They question what makes 'soup' a major part of the meal while 'dumpling' is not. The said reviewer suggests that the distinction lies in the specific verbs being used to prepare starchy foods. However, this will also not work as the verb gba, for example, is also used in the preparation of starchy foods. What this points to is that the verbs can be classified in different ways. The one adopted here looks at the ascent of the semantics of the verb: the semantic focus of the specific activity verbs is the manner as opposed to the focus on result of the general verbs discussed in previous sections. 
Interestingly, the name for the instrument that is used for preparing foods of this kind, 'a wooden ladle, mingling stick' is based on a nominalisation of the verb and prefixed with an appropriate noun class marker: o-gi-ge [CM-RED-drive]. Example 25 describes the stage at which the ladle is inserted for the action of 'driving' to begin.

\section{Otsúgo lokpí ogige ko loge 'vlí pétéé. \\ otsúgo lo-kpí o-gige ko lo-ge \\ now 1PL.DEP-put.in CM-wooden.ladle just 1PL.DEP-drive \\ bulí pétéé \\ 3SG all}

'It is now that we put in the wooden ladle then we stir it.'

We have seen in example 10 (repeated as 26 for convenience) that the general process of preparing a meal involving kımuko 'red rice dumpling' can be described with the general verb tó. The verb ge by contrast is used to describe the specific action of preparing the dumpling. Thus, the opening sentence of the text describing the processes of how one specifically cooks kımuks uses this verb as shown in 27 . Example 26 implies not only the preparation of kımuks but also the preparation of the sauce or soup that goes with it. Example 27 focuses only on the preparation of kımukó. Compare examples 26 and 27.

26. Báátó 'emukó ní Baagbo.

bá-á-tó ki-mukó [ní Baagbo]

3PL-PRSPROG-cook CM-red.rice.dumpling LOC Baagbo

'They are cooking red rice dumpling in Tafi.'

27. Kımukó gige ní Baagbo kılínū sí óspı amó ...

\begin{tabular}{|c|c|c|c|c|c|}
\hline kl-mukś & & gi-ge & ní & Baagbo & ní \\
\hline CM-red.rice.dur & & RED-drive & LOC & Tafi & TOP \\
\hline kılí-nū & sí & o-bo & & & a-mó \\
\hline 3SG.IND-COP & COMP & $2 \mathrm{SG}$ & DE-FL & T-look.for & CM-rice \\
\hline
\end{tabular}

Thus, the verb ge focuses on the activity of preparing the dumpling. In Table 2, it has been shown that Akan also uses a similar verb suggesting a similar and shared conceptualisation of the event. 


\subsection{The verb tú}

The verb tú is a general activity glossed as 'pound'. The preparation of the staple 'fufu' is done by pounding boiled yam, cassava, cocoyam or plantain to produce a starchy paste. This activity is specific to this aspect of preparing the meal. It does not describe the preparation of the accompaniments of the starchy component. Example (28) describes the pounding of a specific ingredient to get fufu while (29) talks of the action of pounding fufu without specifying the particular ingredient that is being pounded to result in the fufu.

28. Ébetú kíkū.

é-be-tú kí-kū.

3SG-FUT-pound CM-yam

'S/he will pound yam.'

29. éé-tǔ fufuo ' $S /$ he is pounding fufu'

In fact, the activity can be applied to other ingredients in the process of food preparation where the result is not fufu. In example (17) repeated here as (30) the pounding of the rice to remove its husk is a precursor to it being roasted.

30. Blı̌ ní, bútú ká logba é.

$\begin{array}{llllll}\text { bľ̌ } & \text { ní } & \text { bú-tú } & \text { ká } & \text { lo-gba } & \text { é } \\ \text { 1PL.IND } & \text { TOP } & \text { 1PL-pound } & \text { then } & \text { 1PL.DEP-roast } & \text { CFM }\end{array}$

'As for us, we pound (the rice) and then roast it.' (Kımukó, line 05)

The Tafi verb tú 'pound' and its uses are closely matched by the Ewe verb tó 'pound'. The Ewe verb is also used to talk about pounding of boiled tubers or plantain into fufu, as well as for pounding grains into flour or for the pounding of nuts such as boiled oil palm nuts. The close form and meaning resemblance suggests that they could be cognate. Other languages like $\mathrm{Ga}$ also have verbs used similarly but which do not resemble the Ewe or Tafi verbs. In Ga, the verb is shí 'pound' and Akan uses wó 'pound'. 


\section{Conclusion}

In the foregoing, I have explored the grammar and meaning of five verbs that belong to the culinary field in Tafi. One cannot describe Tafi cuisine without using these verbs. The discussion has been framed in terms of general cooking verbs which seem to be distinguished at one level in terms of the medium through which the cooking takes place. That is at the basic level, tó applies to cooking in water, gba to cooking in oil and pói to cooking by dry heat. There is also the specialisation of activity verbs for particular actions carried out in producing some foods. The two salient ones are ge 'drive' for making dumplings and tú 'pound' for making fufu. As indicated, all these verbs have other uses and, in some cases, other senses that do not fall within the culinary domain. Nevertheless, the investigation has laid bare the ways in which the various modes of preparing different kinds of food are construed from a linguistic point of view. 
Bobuafor: "Paddling A Canoe and Preparing Rice Balls": The Semantics of Tafi Cuisine

\section{Abbreviations}

$\begin{array}{llll}\text { ADD } & \text { Addressive particle } & \text { INTJ } & \text { Interjection } \\ \text { AM } & \text { Agreement Marker } & \text { LOC } & \text { Locative } \\ \text { CFM } & \text { Clause final marker } & \text { NEG } & \text { Negative } \\ \text { CM } & \text { Class marker } & \text { PERF } & \text { Perfective } \\ \text { CM.PL } & \text { Class marker (plural) } & \text { PL } & \text { Plural } \\ \text { COM } & \text { Comitative } & \text { PROX } & \text { Proximal } \\ \text { COMP } & \text { Complementiser } & \text { PRSPROG } & \text { Present progressive } \\ \text { COND } & \text { Conditional } & \text { PURP } & \text { Purpose } \\ \text { CONJ } & \text { Conjunction } & \text { RED } & \text { Reduplicative } \\ \text { CONN } & \text { Connector } & \text { REL } & \text { Relative marker } \\ \text { COP } & \text { Copula } & \text { REP } & \text { Repetitive marker } \\ \text { DEP } & \text { Dependent } & \text { 1PL } & \text { First person plural } \\ \text { DISJ } & \text { Disjunctive } & \text { 2SG } & \text { Second person plural } \\ \text { DISTR } & \text { Distributive } & \text { 3PL } & \text { Third person plural } \\ \text { FUT } & \text { Future } & \text { 3SG } & \text { Third person singular } \\ \text { IND } & \text { Independent } & \text { SM } & \text { Subject marker } \\ \text { INDEF } & \text { Indefinite } & \text { TOP } & \text { Topic marker }\end{array}$




\section{References}

Bobuafor, Mercy. 2013. A grammar of Tafi. PhD. Dissertation, University of Leiden. (LOT Dissertation Series 327) Utrecht: LOT

Bobuafor, Mercy L. 2009. "Noun classes in Tafi." In The linguistics of endangered languages: morphology and syntax, edited by M. Leo Wetzels, 267-307 LOT Occasional Papers, Utrecht.

Defina, Rebecca. 2016. Events in language and thought: The case of serial verb constructions in Avatime. Dissertation. Radboud University Nijmegen \& Max Planck Institute for Psycholinguistics, Nijmegen.

Essegbey, James. 2010. "Locative constructions in Tutrugbu: Losing typological characteristics due to contact." The Journal of West African Languages. 37(1): 93118.

Fillmore, Charles J. 2006 [1982]. "Frame semantics." In Cognitive linguistics: Basic readings, edited by Dirk Geeraerts, 373-400. Berlin: Mouton de Gruyter

Fillmore Charles \& Atkins B. 1992. "Toward a frame-based lexicon: The semantics of RISK and its neighbors." In Frames, fields, and contrasts: New essays in semantic and lexical organization, edited by Adrienne Lehrer \& Eva Feder Kittay, 75-102. Hillsdale, Erlbaum.

Lehrer, Adrienne. 1974. Semantic fields and lexical structure. Amsterdam: North Holland.

Lehrer, Adrienne \& Kittay Eva Feder. 1992. "Introduction." In Frames, fields, and contrasts: New essays in semantic and lexical organization, edited by Adrienne Lehrer \& Eva Feder Kittay, 1-18. Hillsdale, Erlbaum.

Lyons, John. 1977. Semantics. Cambridge University Press.

Petruck, M. 1996. "Frame Semantics." In Handbook of Pragmatics, edited by J-O Östman, J. Blommaert and C. Bulcaen, 1-13. Amsterdam/Philadelphia, Benjamins.

Simons, Gary F. and Charles D. Fennig (eds.). 2018. Ethnologue: Languages of the World, Twenty-first edition. Dallas, Texas: SIL International. Online version: http://www.ethnologue.com.

Trier, J. 1931. Der Detsche Wortschatz im Sinnbezirk des Verstandes. Heidelberg: Winter.

van Putten, Saskia. 2014. Information structure in Avatime. Dissertation. Radboud University Nijmegen \& Max Planck Institute for Psycholinguistics, Nijmegen. 